\title{
ИНТЕРАКТИВ ЖУРНАЛИСТИКА ШАКЛЛАНИШИНИНГ АСОСИЙ БОСҚИЧЛАРИ
}

\section{Юлдуз Акмаловна АРТИКОВА}

Филология фанлари номзоди, доцент

Телерадио ва халқаро журналистика кафедраси

Ўзбекистон журналистика ва оммавий коммуникация университети

Тошкент, Ўзбекистон

\section{ОСНОВНЫЕ ЭТАПЫ ФОРМИРОВАНИЯ ИНТЕРАКТИВНОЙ ЖУРНАЛИСТИКИ}

\section{Юлдуз Акмаловна АРТИКОВА}

Кандидат филологических наук, доцент

Кафедрf телевидения и международной журналистики

Университет журналистики и массовых коммуникаций Узбекистана

Ташкент, Узбекистан

\section{BASIC STAGES OF FORMATION OF INTERACTIVE JOURNALISM Yulduz Akmalovna ARTIKOVA \\ Candidate of Philological Sciences \\ Associate Professor of the Department of Television and International Journalism \\ University of Journalism and Mass Communications of Uzbekistan, Tashkent, Uzbekistan ortiqovayulduz@gmail.com}

UDC (УЎК, УДК): 070

For citation (иқтибос келтириш учун, для цитирования):

Артикова Ю.А. Интерактив журналистика шаклланишининг асосий босқичлари // Ўзбекистонда хорижий тиллар. - 2021. - № 6 (41). - Б. 191-201.

\section{https://doi.org/10.36078/1644600094}

Received: October 15, 2021

Accepted: December 17, 2021

Published: December 20, 2021

Copyright $(02021$ by author(s) and Scientific Research Publishing Inc.

This work is licensed under the Creative

Commons Attribution International License (CC BY 4.0).

http://creativecommons.org/licenses/by/4.0/

\section{Open Access}

Аннотация. Мазкур мақолада ОАВда интерактив журналистика шаклланишининг асосий тарихий босқичлари масаласи кўриб чиқилди. Телевидение, жумладан, радио хам, аввалдан интерактивликни назарда тутиб ривожланар экан, интервьюлар, аудиториядан келган хатлар, телефон қўнғироқлари бунга яққол мисол бўлади. Интернет ва ижтимоий тармоқларнинг ривожланиши ахборот олиш ва тарқатиш жараёнларини жадаллаштириб, ахборот чексиз, тўсиқларсиз, аудитория фикри акс этиш билан кенг тарқала бошлади Изланишда интернет ва ижтимоий тармоқларда аудитория фикрини акс этиши тележурналистика қатори барча ОАВ фаолиятига қандай таъсир қилиши батафсил тахлил қилинди. Аудитория пассив ахборот қабул қилувчи эмас, эркин сўзловчи, журналистнинг материал тайёрлашдаги ўзига хос хаммуаллифига айланиши, бу хусусият радио қатори тележурналистика ривожида хам ўз ўрнига эга бўлиши, монологик жанрлар ўрнини диалогик дастурлар эгаллаши мақолада батафсил ёритилди. Бу хусусият радио қатори тележурналистика ривожида хам ўз ўрнига эга бўлди. Тадқиқотнинг долзарблиги сифатида интерактив журналистика шаклланиши бевосита жамият демократлашуви билан чамбарчас боғлиқлиги борасидаги фикрларни кўрсатиш мумкин. Шунингдек, мақолада ахборот оқими ва алмашинувининг кескин ортиши аудиториянинг ахборот истеъмолчисидан ахборот ишлаб чиқарувчисига айлантириб, ахборот коммуникация сохаси сиёсий иқтисодий хаётдаги мухим ўринга эга бўлишига тўхталиб ўтилган. Тадқиқотнинг асосий мавзуси журналистикадаги интерактивликнинг шаклланиш босқичлари 
илмий назарий қарашлар ва тарихий мисоллар ёрдамида очиб берилган. Мақолада жахон тажрибаси мисолида интерактив журналистиканинг шаклланиши босқичлари буйича илмий хулосалар қилинди.

Калит сўзлар: аудитория; интерактив журналистика; ижтимоий тармоқ; коммуникация; ижтимоий телевидение; қайтариқли алоқа.

Аннотация. В статье рассматриваются основные этапы становления интерактивной журналистики в СМИ. Телевидение, а также радио стали в первую очередь интерактивными, яркими примерами этого являются интервью, письма аудитории и телефонные звонки. Развитие Интернета и социальных сетей ускорило процесс получения и распространения информации. В статье уточняется тот факт, что аудитория является не пассивным приемником информации, а свободным оратором, соавтором журналиста при подготовке материала, эта особенность имеет место в развитии радио- и тележурналистики, монологические жанры сменяются диалоговыми программами.. Актуальность исследования видится в том, что становление интерактивной журналистики напрямую связано с демократизацией общества. В статье также подчеркивается, что резкое увеличение потока информации и обмена ею превратило аудиторию из потребителя информации в производителя информации и что сфера информации и коммуникации играет важную роль в политической и экономической жизни. Основной темой исследования являются этапы формирования интерактивности в журналистике, которые раскрываются на научно-теоретических взглядах и на исторических примерах. В статье делаются выводы об этапах становления интерактивной журналистики на примере мирового опыта.

Ключевые слова: аудитория; интерактивная журналистика; социальная сеть; коммуникация; социальное телевидение; обратная связь.

Abstract. This article discusses the main historical stages in the formation of interactive journalism in the media. As television, including radio, has evolved to be interactive for a long time, in line with interviews, letters from the audience, phone calls, etc. The development of the Internet and social networks has accelerated obtaining and disseminating information. The study claims that the audience is not a passive receiver of information, but a free speaker, a journalist's co-author in the preparation of material, that is, dialogic programs replaced monologue genres. This feature has a role in the development of radio and television journalism. The relevance of the research can be seen in the idea that the formation of interactive journalism is directly related to the democratization of society. It emphasizes that the sharp increase in the flow and exchange of information has transformed the audience from the consumer of information to its producer and that the field of information and communication plays an important role in political and economic life. The main topic of the research is the stages of formation of interactivity in journalism based on scientific theoretical views and historical examples. The article draws scientific conclusions on the steps of developing interactive journalism on the example of world experience.

Keywords: audience; interactive journalism; social network; communication; social television; feedback. 
Кириш. Бугунги кунда янгилик учун аудитория асосан интернетга мурожаат қилади. Сўнгги янгиликлардан хабар топган фойдаланувчи форумларда у ёки бу масалани фаол мухокама қилади. ОАВ аудиторияни ўзига жалб қила олсагина рақобатга бардош бера олади. Акс холда медиабозорида бошқа муқобилга бўшатиб беришига тўғри келади. Янгиликлар индустрияси конвергенция йўналишида тараққий этмоқда. Материал тайёрлашда мухлислар фикрлари акс этади, оддий одамларниг олган видеоларидан фойдаланилади. Хаваскорларнинг янги медиадаги конвергенцияси кузатилади.

Интерактив журналистика замонавий хаётни акс эттириш бўлиб, бугунги кунда унинг асосий кўриниши сифатида блогларни кўрсатиш мумкин. Ўкувчилар ахборот истеьмолчилари бўлмай, ўзлари мустақил равишда ахборот ишлаб чиқарувчиларига айланишди. Истаган одамнинг ўз фикр қарашларини ижтимоий тармоқларда ифодалаши фуқаролик журналистикаси кўриниши сифатида замонавий интерактив журналистикага мисол бўла олади. XXI аср журналистикаси учун интернет ва ижтимоий тармоқларнинг оммалашуви профессионал журналистика учун жиддий муаммони келтириб чиқарди. Эндиликда мобиль телефонлар алоқа воситасигина бўлмай, фикр алмашиш, ўз қарашларини ифода қилиш, воқеа-ходисаларни тасвирлаб оммага такдим этиш имкониятини хам бермокда.

Асосий қисм. Интерактив журналистика назариясига оид қарашлар ўтган асрда пайдо бўлиб, унинг ўзига хос хусусиятларининг тадқиқига оид изланишлар ғарб олимлари асарларида ўз аксини топади. Бунда интерактивликнинг асоси сифатида коммуникациянинг моделлари, йўналишлари бўйича изланишлар олиб борилади. "Коммуникация назарияси моделлари ўтган асрнинг 50-йилларида Г. Лассвелл ва Т. Ньюкомблар томонидан тадқиқ этилган. Линияли моделда коммуникация жараёни ким? нима сўзлаяпти? қайси каналдан? кимга? қайси эффектда? каби йўналишда кўриб чиқилади. Т. Ньюкомб томонидан тадқиқ этилган иккинчи интерактив моделда коммуникатор ва аудитория ўртасидаги коммуникацияда тўқнашув нуқтаси ўрганилади. Бунда биринчи ва иккинчи моделларда мулоқотдаги ўзаро таъсир қилиш жараёни тахмин қилинади. Шу билан бирга коммуникациянинг диалогик модели ўтган асрнинг 80йилларида россиялик олим Т. М. Дридзе коммутатор ва реципиент ўртасидаги ўзаро тушунишга эришиш нуқтаи назаридан диалогни тадқиқ этган” (10). Албатта, коммуникацияга асосланган интерактивлик деярли барча ОАВ у ёки бу кўринишда ўз аксини топади. Чунки ОАВ аудитория билан мулоқотининг унинг коммуникативлик хусусиятини ўзида мужассам қилади. Матбуот, радио ва телевидениенинг ахборот махсулотлари аудиториянинг фикр ва қарашларини ўзида акс эттириб тарақққий этиши ахборот асрининг бирламчи талабларига айланган эди. Ўтган асрда ахборот асри тушунчаси, дунёнинг “катта қишлоқ” кўринишида ахборий коммуникатив алоқа билан ўзаро боғланиши замонавий тенденцияга айланади. “Ахборотга эгалик қилиш - оламга эгалик" қилиш тенденциясининг яратилиши ахборот асрига замин хозирлайди. Оққора рангдаги, овозсиз кино санъатидан фарқли ўлароқ рангли ва овозли тасвирнинг телевизор орқали намойиш этилиши экран маданияти тушунчасини кенгайтиради. Телевидениенинг ихтироси мутахассислар олдига коммуникациянинг визуал ва хаётга яқинлаштирилган эффектини берувчи ОАВ асрини тадқиқига асос яратди. "П. Бурдье, Н. Луман, М. МакКлюэн, Т. Рантанен, Ф. Уэбстер, 
Дж. Фиске каби хорижлик олимлар тадқиқотларида телевидение пайдо бўлиши ва ривожланиши хамда жамият билан ўзаро таъсир қилиш жараёнлари акс этган” (7).

Телевидение медиа сохасини улкан бизнес оламига олиб кирди. Томошабинлар эшитганларига эмас, кўрганларига кўпроқ ишонишди. "Минг бора эшитгандан кўра, бир бора кўрган афзал" нақли телевидениенинг тасвирий таъсирчанлигини белгилаб берди. Аудитория телевидениенинг мўьжизасига махлиё бўлиш билан бирга, ўз кўзлари билан кўрган маълумотларини хақиқат сифатида қабул қилишади. Бу хусусият телевидение орқали берилган маълумотларнинг нафақат таъсирчан, балки самарали эканлигини исботлаб берди. Собиқ Совет давлатларида телевидение ғоявий мафкуравий пропаганда воситаси сифатида хизмат қилган бўлса, аксарият ғарб давлатларида телевидение медиабизнеснинг бир бўғини сифатида тижорийлашди. Реклама, хомийлик асосида тайёрланган дастурлар истеъмолчи сифатида қабул қилинадиган аудиторияни реклама қилинаётган махсулотларни харид қилиш орқали “фаровон турмуш сари етаклаш”ни мақсад қилди. Совет пропаганда воситаси сифатидаги телевидение эса коммунистик идеологиясини аудиторияга сингдиришни ўз олдига мақсад қилиб кўйди.

Аудитория манфаатларига хизмат қилувчи тижорий манфаат ва пропагандадан холи бўлган ОАВ Буюк Британияда вужудга келди. Ўтган аср бошларида: “Буюк Британияда ижтимоий телерадиоканал ташкил этилган. 1920 йилда ВВС корпорациясига асос солиниб унга Жон Рейт рахбарлик қилишни бошлаган. Ижтимоий телерадиоканал асосини уч тушунчага таянилиб хосил қилинган: “ахборот бериш, маърифат тарқатиш ва хордиқ чиқариш" - "inform, educate and entertain". Европа давлатлари ичида илк бор бу ерда ижтимоий телерадиоканал талабларига асос солиниб, ташкилот фаолиятининг тамойиллари ишлаб чиқилган" (2). Ижтимоий телерадиоканаллар жамият, аудитория манфаатларини кўзлаши билан фарқланади. Радио, хусусан, телевидение ташкил этиш, уни доимий фаолият юритиши нихоятда катта молиявий ресурсларни талаб қилгани учун бу соха монополлашади. Монопол ОАВларда аудиториянинг қизиқишлари акс этмай шахсларнинг манфаатлари назарда тутилади. Томошабин ва тингловчилар берилаётган ахборотнинг таъсир этувчи объектига айланади. Давлат ихтиёридаги ОАВлар учун аудитория сиёсий пропаганданинг таъсир объекти бўлиб хизмат қилади. Ахборот иккала вазиятда монолог шаклда тақдим этилиб, аудитория ахборотнинг истеьмолчиси бўлади. ОАВга эгалик қилувчилар ижтимоий онгни шакллантирадилар, аудиторияни, яъни ахолини ўз таъсири остида бўлишига интиладилар. Масалан, XX аср бошларида тараққий этишни бошлаган, эндигина оммалашаётган радио сиёсий кучларнинг куролига айланиб, хурфикрлилик ва эркинлик ғояларига зид “радиоуруш”, "радиопропаганда” тушунчалари пайдо бўлган. Тарихий мисолларга мурожаат қилсак: "Гитлер учун радио ташқи тарғиботнинг асосий воситаси бўлиб қолди. Австриядаги хукуматни ағдариш учун у 1933 йили кучли радиоурушни бошлаб, Саарадаги плебисцит даврида радиодан унумли фойдаланган. Радиопропаганданинг таъсирини кучайтириш учун Геббельс 1936 йили барча давлатларда кўп микдордаги арзон радиоприёмниклар таъминотини ташкил этди. Умуман олганда, бу даврда жонли сўзнинг имкониятлари нацист пропагандаси учун жуда кўл келди" (5). Радионинг таъсири ўша пайтларда шу даражада кучли эдики, ғояларга хизмат қилувчи бошқа 
бир курол радио каби унумли эмас эди. Совет тузумининг тарғибот воситаси бўлган радио кенг оммага коммунизм ғояларини сингдирувчи, бу ғояларга одамларни буйсундирувчи қурол бўлиб хизмат қилди. Барча тоталитар тузумлар каби совет тузуми бутун халқни ягона гегемон мафкурага бўйсундирди. Демак, ОАВ нафақат демократик, шу билан бирга, автократик тузумга хам хизмат қилиши мумкин. Хамма гап ундан қандай мазмун ва шакл, қай мақсадларда фойдаланишдадир. Ижтимоий телерадиоканаллар жамият манфаатларига, қизиқишларига хизмат қилиши билан демократик ОАВ сифатида алохида эътирофга лойиқ. "Public service broadcasting" тизимидаги ижтимоий телерадиоканаллар фаолиятида ОАВ нацист, совет каби ғоявий-мафкуравий курол ёки молиявий таъсир воситаси бўлиб эмас, жамият манфаатларини химоя қилувчи, холис ва хаққоний ахборот етказувчи ахборот воситаси сифатида фаолият куурсатади. Тарих тажрибасига кўра - айнан шу йўналишдаги телерадиоканаллар инсонпарварлик нуқтаи назаридан умуминсоният тараққиётига хизмат қилади. Интерактив журналистикада хам айнан аудитория фикри, қарашлари, диди ва хохишлари намоён бўлиши билан ижтимоий телерадиоканалларнинг фаолият йўналишига мослиги билан ахамиятлидир. Эволюцион тараққиёт натижасида ўтган асрнинг ўрталаридан бошлаб радио, телевидение фаолиятида интерактивлик хусусияти аста- секин ривожлана бошлади. Ахборот монологик тусдан диалогик кўринишга эга бўлиб, томошабин ва тингловчилар ўз фикрларини эфирда ифода этишни бошлашди. Интерактив журналистиканинг келиб чиқиш тарихини россиялик тадқиқотчи Е. А. Стрельникова шундай таърифлайди: "Ўтган асрнинг 20йилларидан бошлаб радио ривожланишининг барча босқичларида тингловчи билан мулоқот кузатилган. 60-йилларда тадқиқотчилар бундай усулдаги дастурларни “контактли” деб таърифлашган. 70йилларда тингловчилардан келаётган хатлар асосида ташкил этилган эшиттиришлар қайтариқ алоқали дастурлар сифатида талқин этилган. 90-йилларнинг иккинчи ярмида хориждан, хусусан, АҚШдан кириб келаётган медиамаданият кўринишлари билан бизнинг матбуотга у «интерактив радио» деган янги илмий атама сифатида тасниф этилди" (3). Ўтган асрда АҚШнинг медиа маданиятини тахлил қилган мутахассис В. Голованов бу жараён хусусида шундай дейди: "Хаётга яқинлаштирилган эфир - АҚШ замонавий радиосининг улкан воситасидир. Студияларни ТВга тақдим этиб, радио тингловчи ва реклама долларлари учун рақобатли жангда ғолиб бўлиш усулини топди" (1). Демак, интерактив журналистика тамойиллари ўтган асрнинг ўрталаридан бошлаб АҚШ ва Ғарбий Европа мутахассислари томонидан кенг тадқиқ қилинган. Хусусан, аудитория ва унинг коммуникатив тамойилларини ўрганувчи махсус илмий текшириш институтлари фаолият кўрсатишни бошлади. Аудиториянинг эркин фикр билдириши, жамиятда ахборотнинг чегарасиз алмашинувига замиин хозирлайди. Ахборотнинг эркин тарқалиши ижтимоий хаёт ва кишилик турмуш тарзига хам бевосита таъсир қилди. Интеллектуал сохалар кенг тараққий этиб, мулоқот шаклидаги коммуникатив касбий хунарларга эхтиёжни пайдо қилди. Ғарб мутахассиси Р. Инглегартнинг таъкидлашича, “АҚШ, Канада ва Ғарбий Европадаги ишчиларнинг асосий қисми фабрикадан ташқарида фаолият кўрсатмоқда. Аксарият одамлар механик дунёда яшамай, бошқалар билан мулоқот шаклида хизмат қилишмоқда. Инсонларнинг асосий кучи ишлаб чиқаришга эмас, ахборот олиш ва тарқатишга йўналтирилган. Бунда янгиликка 
интилиш ва билимли бўлишнинг ахамияти янада ортмоқда" (4). Шундай қилиб, ахборот алмашувининг жадаллашиши жамиятдаги иқтисодий ривожланишга замин бўлиб, ахборотга эгалик қилиш миллий ва шахсий камолотга етишишнинг мухим омили даражасига кўтарилди. Фикримиз далили сифатида аниқ мисолларга мурожаат қилсак: “1980 йилларга келиб ривожланган мамлакатлар ичида АҚШ мисолида оладиган бўлсак, ўша даврда 3\% ахоли қишлоқ хўжалиги билан шуғулланган бўлса, 20\% одамлар хизмат кўрсатиш сохасида банд бўлиб, 48\% мутахассислар ахборот олиш ва тарқатиш билан машғул бўлганлар" (9). Албатта, бу каби хусусият ОАВдаги туб ўзгаришлар, жумладан, ахборот воситаларининг монологик фаолиятдан диалогик фаолиятга ўтишлари билан тубдан боғлиқ. Журналистика барча ижтимоий сохалар каби бевосита жамиятдаги ўзгаришлар билан узвийлашган экан, диалогик, ўзаро таъсирланиш, ўзаро ахборот алмашинувига асосланган фаолият юритишлик ОАВнинг асосий функцияларига ўзига хослик бахш этди. Жумладан, ўтган аср ўрталарида телевидение фаолиятида интерактивлик туб бурилиш ясади. "Ўтган асрнинг 60-йилларида томошабин фаол бўлган кўрсатувлар эфирга узатилган. ИТВ телеэфир нуқтаи назаридан ўз табиатига кўра диалогикдир. Монологик эфир узатишдан бу йўналишнинг асосий фарқи — томошабин бунда телекоммуникатор таъсир объекти бўлмай, телевизион жараённинг субъекти ва фаол хамкоридир. Бунда диалог - почта, телефон, микрофон, видеоканал, пейджер, интернет каби қайтариқли алоқа воситалари ёрдамида томошабин билан коммуникаторнинг ўзаро таъсирига асосланган. Томошабин телевизион фаолиятга фаол киришиб, телекўрсатув тайёрлашда иштирок этган. Ўтган асрнинг 90-йилларига келиб интерактив телевидение атамаси кенг қўлланила бошлади. Интерактив журналистика тахририят жамоаси билан аудитория муносабатларининг ўзгаришларига таянилади. ОАВнинг оммага бир томонлама монологик таъсиридан журналистларнинг ўқувчи, тингловчи, томошабинлар билан диалогик муносабатлари асосида ўзаро мулоқоти, хамкорликдаги фаолияти, ахборот алмашинувини назарда тутади. Бу муносабатлар уларни тўлақонли ахборот хамкорларига айлантиради" (8). Кўпгина тадқиқотчилар интерактивликнинг асоси сифатида диалогик жанрларнинг асосий кўриниши бўлган интервью жанрига алохида эътибор қаратишади. Чунки икки киши ууртасидаги мулоқот асосида интервью жанрининг мавжудлиги хеч кимга сир эмас. "Интервью жанридаги контактда турли масалалар ечимига қаратилган диалог мавжуд. Унинг функционал вазифаси контакт натижасида аудитория ўзи учун янги маълумотларни биринчи шахсдан олишидир" (10). Интервью жанри журналистик жанрларнинг энг мумтоз кўринишларидан бири бўлиб, барча журналистик йўналишларида, жумладан, матбуот, радио, телевидение ва интернет журналистикада бу диалогик жанрнинг алохида ўрни бор. Интерактив журналистика хам интервью жанрининг барча хусусиятларини ўзида жамлаган холда, мулоқотдаги коммуникаторларни тенг хуқуқли қилиши билан ахамиятлидир. Яъни интерактив журналистикада савол берувчи ва унга жавоб берувчи мақомлари мавжуд бўлмай, коммуникациянинг иккала субъекти ўзаро фикр берувчи, ўзаро бир-бирига таъсир этувчи тенг хуқуқли мулоқот иштирокчиси сифатида алоқага киришадилар. Мазкур фикрга таянилиб, интерактив журналистиканинг тараққиёти даврини журналистика илк пайдо бўлган даврларда эмас, айнан ўтган асрнинг 
ўрталаридан тадқиқ этиш тўғри деб белгиладик. Интерактив журналистика билан журналистика интерактивлигининг алохида тафовутлари мавжуд. Масалан, интервью жанри бунга яққол мисол бўла олади. Интервью жанрида журналистиканинг интерактивлик хусусиятлари жам бўлган.

Натижалар ва мухокамалар. Интерактив журналистиканинг ўзига хос хусусияти бўлган қайтариқли алоқа шакли сифатида мухлислардан келган хатларни белгилаш мумкин. Хатларда аудитория вакилларининг фикр мулохазалари акс этади, уларда тайёрланган материалларга мухлисларнинг муносабатлари акс этади. Ўтган асрларда хатлар тингловчи ва томошабинларнинг фикрларини акс эттирувчи асосий восита хисобланган. Хатлар дастур самарадорлигини белгиловчи асосий омил бўлиб, аудиторияни тадқиқ этиш учун социологик тахлилга асос бўлиб хам хизмат қилган. "Хатлар тахлилида журналист билан аудитория вакилининг мулоқотида конкрет масала бўйича ижтимоий фикрнинг шаклланиши бўлади. Матнинг функционал вазифаси мухокама қилинаётган муаммо юзасидан аудиторияни фикр билдиришга ундашдир. Хатлар шархини тайёрлаётган журналист ўқувчилар билан диалогга киришади. У хатлардан ижтимоий фикр акс этадиган, мавзу буйича билдирилган ўзига хос қарашларни танлаб олади. Шундан сўнг у хатларнинг мухокамасига ўтиб, уларга ўз муносабатини билдиради" (10). Ўзбекистон радиосининг барча каналларида хатларни тахлил қиладиган бўлим фаолият кўрсатиб, хатлар асосида тайёрланадиган махсус эшиттиришлар бўлган. Жумладан, "Хатларни ўқиганда", “Савол беринг — жавоб берамиз”, “Мактублар-дил изхори” каби сахифа ва рукнлар тўғридан-тўғри хаво мавжларига чиққан. Телевидениега хам келган хатлар алохида эътирофга лойиқ. Жумладан "Ёшлар" телеканалидаги "Ватанпарвар" харбий-ватанпарварлик йўналишдаги кўрсатувда махсус “Аскар мактублари” номдаги рукн мавжуд бўлиб, унда аскарлардан келган хатлар эфирда бошловчи томонидан ўқиб эшиттирилган. Аммо хатлар интерактив журналистиканинг тўлақонли кечиши учун етарли эмас. Бунинг учун замонавий техникавий имкониятларнинг тараққиёти хам зарур. Тўлақонли интерактивлик хаммабоп "broadcasting" технологияси тизимидан «narrowcasting" ва “индивидуал" тизимга ўтишни белгилайди. «Broadcasting” тизими хозирда юртимизнинг барча телева радиостудияларида қўлланилади. Яъни бунда эфирга узатиладиган ахборот турли аудитория учун бир хил бўлади. Тингловчи эса узатиладиган материалнинг пассив қабул қилувчиси эди. "Narrowcasting" ва «индивидуал" (баъзи маълумотларда “шахсий”, “персонал”. - Ю.А.) тизимида эса тингловчи ва мухлислар ахборотни ўз хохишларига кўра ўзгартирадилар, ўзларига керагини танлаб оладилар, узатилаётган маълумотларга қўшимчалар қиладилар. Шундан келиб чиқиб, интерактив дастурларни баъзи мутахассислар тингловчиларга мослашадиган эфир жараёни деб хам таърифлашади. Жумладан, одатда Ғарбда интерактив телевидениени “мухлисларга мослашадиган телевидение" шаклида кўллашади. "Ўтган асрнинг охирларида америкалик тадқиқот марказларида компьютер технологиялар билан телевидениенинг уйғунлигидаги махсулот бўлган «interactive media» атамаси пайдо бўлди. «Interactive media»да икки томонлама ахборот алмашинуви назарда тутади" (7). Изланишлар натижасида томошабинлар учун қатор қулайликларни жамлаган турли лойихалар ишлаб чиқилган. Ижтимоий телевидение тараққий этган 
Буюк Британияда спорт журналистикасида интерактив лойихаларнинг пилот варианти таклиф этилади. Маълумки, спорт журналистикаси техник ўзлашмаларни амалиётга тадбиқи бўйича ўзига хос кашшофлик қилади. Янги русумдаги камералар, энг сўнгги тиниқликдаги тасвирга олиш ускуналари айнан йирик спорт тадбирларида томошабинларнинг эътиборига хавола қилинади. Илк интерактив телевидение имкониятлари хам ана шундай янгича ёндашувни намоён қилди. "1999 йил август ойида Буюк Британия ахолиси интерактив телевидение билан танишадилар. Мамлакатдаги етакчи рақамли компания бўлган British Sky Broadcasting томошабинларга "Sky Sports Extra" номли интерактив телеканални тақдим этди. Томошабинлар экранларида телевизион репортажлар яратувчилари бўлишди. Пультдаги тугмаларни босиш орқали улар тасвир кууриниши ва шаклига ўзгартириш киритиш имконияти пайдо бўлди. Хар қандай холатни такроран кўра олиш шароити мавжуд бўлган бу мослама орқали мухлислар репортаж доирасида исталган статистик маълумотларни топиб ўқиш имкониятига эга бўлишди. Спорт мусобақалар бунда узлуксиз давом этган. 1999 йил октябрь ойида АҚШнинг Лос Анжелес шахрида хам интерактив телевидениенинг тантанали очилиш маросими бўлиб ўтади" (2). Мазкур телеканалларнинг фаолияти омадли келади ва тез орада интерактив телевидение дунёда оммалашишни бошлайди. Унинг асосида аудиторияга тасвирни исталган кадридан танлаб кўра олиш, кўрсатилаётган материалга фикрмулохазаларини билдириш, воқеа- ходисалар борасида кўшимча ахборотга эгалик қилиш имкониятлари мухлисларга тақдим этилади. Техник имкониятлар мақсадли аудиторияни ахборот махсулотини яратишда тенг хуқуқли коммуникация субъектига айлантиради. Уларни телевизион пульт тугмаларини босиб, берилган ахборотни кўриб ўтирадиган пассивликдан - ахборотга буюртма берувчи, уни ўз истагича ўзгартирувчи фаолликка ундайди. "Интерактив техника маълумотни пассив қабул қилувчиларни фаол ахборот ишлаб чиқарувчи бўлишларига хисса кўшади. Хаваскорлар проффесионалларнинг репортажларига изох қолдириш билан бирга кўрган-кечирган воқеаларни хам тақдим этадилар. Бунга мобиль телефонларнинг техник имкониятлари ўз хиссасини кўшадилар" (8). Интерактив радиолойихалар, интерактив теледастурлар аудитория эътиборига тушади. Фикрини билдириш имконияти мавжуд бўлган эшиттириш ва кўрсатувлар мухлисларни жалб қилади. ОАВ бу йўналишда ишлай бошлаганларида рейтингларини оширадилар, кенг қамровли мухлисларни ўзларига жалб қиладилар. Эфир диалогик мулоқотга асосланади. Эндиликда радиотўлқинларда, эфирда мутасадди рахбарлар, хукумат вакилларинигина кўриш ва эшитиш эмас, балки оддий одамларнинг хаёти ва қизиқишлари билан танишиш имконияти пайдо бўлади. Интерактив журналистика эфирни халқчиллаштиради, уни кундалик хаётдаги икки кишининг содда ва самимий мулоқотига яқинлаштиради. "Интерактив мулоқот масофаларни йўотиб, микрофон олдидаги одам билан оддий одам орасидаги дистанцияни хам қисқартиради. Тингловчининг мехмон ёки бошловчи билан ўзаро сухбати, жонли эфирда фикрини ифода қилиши, уни миллионлар тинглай олиши бошловчи билан аудиторияни бирбирига яқинлаштиради, уларни бир поғонага кўяди” (6). Эфирни одамларга яқинлаштириш жамиятни демократлаштириш, журналистикани аудитория манфаатларига хизмат қилдиришга замин хозирлайди. Мухим давлат тадбирлари тафсилотлари қаторида оддий 
одамлар хаётидаги воқеалар аудиторияга тақдим этилиши ОАВ ижтимоий ахамиятини оширади. Аудитория вакиллари учун телеэкранларда ўзларини кўриш, радиода овозларини эшитиш нихоятда ёқимли бўлади. Интерактив журналистикада эфир аудиторияга тақдим этилиб, оддий ахоли учун оммавий минбарга айланади. "Хаваскор видеолар буйича хамкорлик телевидение учун янгилик эмас. "Реople" хамда "TV Guide" журналларида АҚШнинг хонадон видеоларига бағишланган ток-шоуларида қатнашиш учун барча хохловчиларга ўзлари тасвирга туширган хазил видеоларни юборишга таклиф қилинган эълонларни чоп этишади. АҚШнинг АВС компанияси хар куни 700 дан 1500 гача видеокассеталарни қабул қилишади” (7). Хозирда жахонда интерактив телевидение ўзининг бажараётган функциясига қараб интернет-еnhanced TV, шахсийpersonalTV, интерактив-interaktiv TV, ақлли-уй Smart Home каби тўртта каби йўналишларда фаолият юритади.

Хулоса. Тарихий жараёнларни кузатар эканмиз, монопол тарзда ахборот узатиш аудиторияни пассив ахборот олувчига айлантириши баробарида, ОАВ пропаганда қуроли ёки молиявий манфаат олиб келувчи восита бўлиб хизмат қилишга мажбур қилади. Интерактивлик жамиятнинг демократлашуви талабларидан бири бўлиб, унинг тараққиёти кўп жихатдан ижтимоий сиёсий ўзгаришлар билан чамбарчас боғлиқ. Телевидение, жумладан, радио хам, аввалдан интерактивликни назарда тутиб ривожланган. Оддий одамлардан олинган интервьюлар, аудиториядан келган хатлар, телефон қўнғироқлари бунга яққол мисол бўлади. Техникавий шароитдан келиб чиқиб, қайтариқли алоқанинг хат, телефон қўнғироқлари каби шакллари тезкорлик касб этмасада, аудиториянинг муносабати нуқтаи назаридан ўз қадрига эга бўлган. Хатлар асосида махсус лойихалар эфирга берилиши бунга яққол мисол бўла олади. Ўтган асрда ривожланишни бошлаган интернет ва ижтимоий тармоқлар ахборот олиш ва тарқатиш жараёнларини жадаллаштирди. Ахборот чексиз, тўсикларсиз, аудитория фикри акс этиш билан кенг тарқала бошлади. Бу хусусият тележурналистика қатори барча ОАВ фаолиятига таъсир қилди. Интернет журналистикаси босма матбуот учун жиддий рақобат туғдирди. Блогларнинг оммалашуви, уларда эркин фикр билдирилиши матбуот олдига конвергентлашиш шартларини қўйди. Ижтимоий тармоқларда фойдаланувчиларнинг изох қолдириш имкониятининг пайдо бўлиши аудиториянинг эркин фикр билдириш, муносабатини ифода қилиш эхтиёжларини қондирди. Аудитория эндиликда пассиб ахборот қабул қилувчи эмас, эркин сўзловчи, журналистнинг материал тайёрлашдаги ўзига хос хаммуаллифига айланди. Бу хусусият радио қатори тележурналистика ривожида хам ўз ўрнига эга бўлди. Монологик жанрлар ўрнини диалогик дастурлар эгаллади. Интерактивлик хусусияти рақобат мухитидаги талаб ва таклиф асосида фаолият кўрсатадиган ОАВ олдига ўз талабларини кўйди. Бундай шароитда, улар аудитория қизиқишлари, хохишлари, истаклари, имкониятларидан келиб чиқиб фаолият кўрсатишларига тўғри келди. Аудитория вакилларининг хикоялари акс этган материалнинг эфирга берилиши, томошабинларнинг истакларидан келиб чиқиб дастурнинг мавзуси, тадрижий давоми белгиланиши, студиядаги томошабинлар саволлари асосида тузилган лойихаларнинг оммалашуви бунинг белгисидир. Медиабизнес шароитида интерактивлик хусусияти акс этмаган дастурлар эфирда катта рейтингга эга бўлмаслигини давр кўрсатди. Ўтган асрдан бошлаб ахборот оқими ва алмашинувининг 
кескин ортиши аудиториянинг ахборот истеъмолчисидан ахборот ишлаб чиқарувчисига айлантирди. Ахборот коммуникация сохаси ижтимоийликдан нуфузи ортиб, сиёсий иқтисодий хаётдаги мухим ахамиятга эга бўлди. Ривожланган давлатларда аксарият ахоли ишлаб чиқариш сохасида эмас, ахборот тайёрлаш, тарқатиш сохасида фаолият кўрсата бошлади. Ахборот коммуникация сохаси ишлаб чиқариш, хизмат кўрсатиш, таълим ва тиббиёт каби сохаларга хам кириб келди. ОАВ нинг ахборот ишлаб чиқаришдаги монопол вазияти кескин камайди. Ижтимоий тармоқлар барча сохаларда фойдаланувчилар билан мулоқот шаклини яратиши билан иқтисодий тараққиётда мухим роль ўйнай бошлади. ОАВ ўз аудиториясини йўқотмаслик учун интернет ва ижтимоий тармоқлар билан уйғун холда ривожланишни бошлади. Бир муддат вақт оладиган хатлар ўрнини шу вақтнинг ўзида уланадиган телефон қўнғироқлари, аудиториядан келиб тушадиган саволлар, ижтимоий тармоқдаги ахолининг муносабати каби қайтариқли алоқа шакллари эгаллади. Интернетнинг тезкорлик хусусиятининг оммалашуви теледастурларнинг хам имкон қадар жонли тарзда эфирга берилишига эхтиёж пайдо қилди. Натижада телеканаллар контентида сухбат, бахс мунозара шаклидаги дастурлар оммалашди. Студияда аудитория таклиф этиладиган дастурлар кўпайди, ижтимоий, маданий, маиший мавзудаги масалаларга бағишланган лойихалар телеканаллар тараққиётини белгиловчи омилга айланди.

\section{Фойдаланилган адабиётлар}

1. Голованов В. США. Радио и ТВ: Стратегия конкурентной борьбы // Телевидение. Радиовещание. - 1972. — № 10. - С.42-44.

2. Социология журналистики. Конспект лекций / Авт.-сост. Е. И. Дмитриев. - Мн.: БГУ, 2001. - 150 с. — URL: https://uchebnikfree.com/uchebniki-jurnalistika/interaktivnost-sredstvahmassovoy-6387.html

3. Стрельникова Е.А. Интерактивное вещание на региональном радио: на примере Оренбургской области. Дисс. на соиск. уч. ст. кан. фил. наук. - М., 2007. - 26 с.

4. Инглегарт Р. Новая постиндустриальная волна на Западе / под редакцией В.Л. Иноземцева. - Москва: Академия, 1999. - С. 245-260. 5. Почепцов Г. Теория и практика коммуникации. - Москва: Центр, 1998. $-150 \mathrm{c}$.

6. Шопен Н. Интерактивность - это пульс жизни http://www.relga.ru/Environ/WebObjects/tguwww.woa/wa/Main?textid=168\&level1 $=$ main $\&$ level $2=$ articles

7. Ятчук О.М. Интерактивный контент современного ТВ. http://jurnal.org/articles/2013/fill11.html

8. https://bstudy.net/736820/smi/interaktivnost zhurnalistiki_problemy www.glossary.ru

9. https://ozlib.com/886019/zhurnalistika/interaktivnaya_zhurnalistika

\section{References}

1. Golovanov V. Televidenie. Radioveshchanie, 1972, No.10, pp. 42-44.

2. Sotsiologiya zhurnalistiki. Konspekt lektsii (Sociology of journalism. Lecture notes), Minsk: BGU, 2001, 150 p. Available at: https://uchebnikfree.com/uchebniki-jurnalistika/interaktivnost-sredstvahmassovoy-6387.html 
3. Strel'nikova E.A. Interaktivnoe veshchanie na regional'nom radio: na primere Orenburgskoi oblasti (Interactive Broadcasting on Regional Radio: on the Example of the Orenburg Region), Extended abstract of candidate's thesis, Moscow, 2007, $26 \mathrm{p}$.

4. Inglegart R. In: "Novaya postindustrial'naya volna na Zapade" (A new post-industrial wave in the West), Moscow: Academia, 1999, pp. 245-260 (262 p).

5. Pocheptsov G. Teoriya i praktika kommunikatsii (Theory and Practice of Communication), Moscow: Tsentr, 1998, $150 \mathrm{p}$.

6. Shopen N. http://www.relga.ru/Environ/WebObjects/tguwww.woa/wa/Main?textid=168\&level $1=$ main\&level $2=$ articles

7. Yatchuk O.M. http://jurnal.org/articles/2013/fill11.html

8.https://bstudy.net/736820/smi/interaktivnost_zhurnalistiki_problemy

9. www.glossary.ru

10.https://ozlib.com/886019/zhurnalistika/interaktivnaya_zhurnalistika 